Article

\title{
Glacial Lake Inventory and Lake Outburst Flood/Debris Flow Hazard Assessment after the Gorkha Earthquake in the Bhote Koshi Basin
}

\author{
Mei Liu ${ }^{1,2}$, Ningsheng Chen ${ }^{1, *}$, Yong Zhang ${ }^{1,2}$ and Mingfeng Deng ${ }^{1}$ \\ 1 Key Laboratory of Mountain Hazards and Surface Process, Institute of Mountain Hazards and Environment, \\ Chinese Academy of Sciences, Chengdu 610041, China; lmeimei90@163.com (M.L.); \\ zhangyongcas@163.com (Y.Z.); dmf@imde.ac.cn (M.D.) \\ 2 University of Chinese Academy of Sciences, Beijing 100049, China \\ * Correspondence: chennsh@imde.ac.cn; Tel.: +86-13808171963
}

Received: 31 December 2019; Accepted: 5 February 2020; Published: 10 February 2020

check for updates

\begin{abstract}
Glacial lake outburst floods (GLOF) evolve into debris flows by erosion and sediment entrainment while propagating down a valley, which highly increases peak discharge and volume and causes destructive damage downstream. This study focuses on GLOF hazard assessment in the Bhote Koshi Basin (BKB), where was highly developed glacial lakes and was intensely affected by the Gorkha earthquake. A new 2016 glacial lake inventory was established, and six unreported GLOF events were identified with geomorphic outburst evidence from GaoFen-1 satellite images and Google Earth. A new method was proposed to assess GLOF hazard, in which large numbers of landslides triggered by earthquake were considered to enter into outburst floods enlarge the discharge and volume of debris flow in the downstream. Four GLOF hazard classes were derived according to glacial lake outburst potential and a flow magnitude assessment matrix, in which 11 glacial lakes were identified to have very high hazard and 24 to have high hazard. The GLOF hazard in BKB increased after the earthquake due to landslide deposits, which increased by $216.03 \times 10^{6} \mathrm{~m}^{3}$, and provides abundant deposits for outburst floods to evolve into debris flows. We suggest that in regional GLOF hazard assessment, small glacial lakes should not be overlooked for landslide deposit entrainment along a flood route that would increase the peak discharge, especially in earthquake-affected areas where large numbers of landslides were triggered.
\end{abstract}

Keywords: glacial lake outburst flood (GLOF); debris flow; Bhote Koshi; landslides; Gorkha earthquake; hazard assessment

\section{Introduction}

Many studies have demonstrated that most glaciers are retreating because of global warming and that the meltwater makes an important contribution to the development of glacial lakes in the Himalayas [1-5]. The sudden emptying of these lakes due to dam overflow and moraine or ice dam failure releases large volumes of water and sediment in destructive events called glacial lake outburst floods (GLOF) [6,7]. In the Himalaya region, at least 62 GLOF have been reported, which caused catastrophic destruction and fatalities in downstream regions [8-12]. The peak flood discharge can easily attain tens of thousands of $\mathrm{m}^{3} / \mathrm{s}$ and travel more than $100 \mathrm{~km}$ away [8,13]. Given their high magnitude discharge and long runout distance characteristics, the GLOF impact is sometimes transboundary, especially in the Himalayas. More than 10 GLOF events originated in Tibet, and the catastrophic floods killed hundreds of people and destroyed much infrastructure downstream, causing enormous damage in Nepal and India [14,15]. As a result, GLOF hazard assessment is receiving increased attention from researchers and governments. 
In previous GLOF hazard assessment studies, only glacial lakes with an area $>10^{5} \mathrm{~m}^{2}$ or volume $>10^{6} \mathrm{~m}^{3}$ were considered to be risky of outburst $[15,16]$. However, some small outbursts occurred in the high mountain regions, but are often ignored due to the limited scale of the events or difficult access [17]. Veh [18] detected 10 previously unreported GLOF from Landsat time series in a study area covering only $10 \%$ of the Hindu Kush Himalayan region. In addition, glacial lake outburst floods are highly unsteady flows characterized by pronounced changes as they propagate down to the valley [13]. The outburst flood can change from a normal flood to a hyperconcentrated flow or debris flow [19,20], and the volumes and peak discharges can increase several to ten times owing to erosion, slides from lateral slopes, sediment entrainment and bulking process along the flow path [21,22]. As an example, in Norway, a glacial lake outburst flood developed into a debris flow due to erosion and blockage, and the volume increased nearly ten times from 25,000 to $240,000 \mathrm{~m}^{3}$ [23]. Sediment can be entrained by scouring unconsolidated deposits of the channel bed, or eroding landslide and collapse of lateral slopes [24,25]. In the seismic belts, large numbers of weak structures and broken rocks are developed along the active fracture zone, and the soils become looser after an earthquake [26]. Studies showed that large earthquakes, such as the Chi-chi earthquake and Wenchuan earthquake, trigger many collapses and landslides, resulting in an increase in loose deposits [27,28]. Although rare reported GLOF events in the Himalaya are directly triggered by earthquakes [29], the loose deposits and landslides induced by earthquakes may affect the magnitude and impact of GLOF. Therefore, it is necessary to build a GLOF hazard assessment model, considering small glacial lakes and the scenario of glacial lake outburst debris flows after earthquakes, especially in areas where many collapses and landslides have developed along the channels.

The Bhote Koshi Basin across China and Nepal, is a highspot area of glacial lakes and GLOF events (Wang and Jiao, 2015). Four glacial lakes have experienced six GLOF events since 1935 (Figure 1). Taraco Lake failed on 28 August 1935, and the GLOF damaged more than $10 \mathrm{hm}^{2}$ of wheat fields (Lv, 1999); The Jialongco GLOF occurred on 23 May and 29 June 2002, which caused 7.5 million yuanin economic losses in Nyalam County (Chen et al., 2007). The Cinrenmaco Lake experienced two GLOF events, first in 1964 and second on 10 July 1981. The GLOF in 1981 had the most destructive effects, in which more than 200 people were killed in Nepal, and the total losses were estimated at approximately three million dollars [14,30]. The latest GLOF event occurred on the night of 5 July 2016, which was caused by Gongbatongshaco (GBTSC) Lake in the Zhangzangbo Valley. GBTSC is a small moraine-dammed lake, with a surface area of $1.7 \times 10^{4} \mathrm{~m}^{2}$ and it was almost empty after the outburst. Although it only released $1.1 \times 10^{5} \mathrm{~m}^{3}$ of water, the peak discharge reached $2400 \mathrm{~m}^{3} / \mathrm{s}$ at Khukundol, $30 \mathrm{~km}$ downstream from the lake, due to severe erosion and sediment entrainment [31]. The GLOF caused severe damage downstream of Bhote Koshi, damaging 77 houses, 3 bridges and the Araniko Highway, and destroying the intake dam of the Upper Bhote Koshi Hydropower Project in Nepal (Figure 1). The 2016 GLOF damage sits within the area affected by the Gorkha earthquake (magnitude M 7.8 in 2015), where extensive landslides and rockfalls were triggered on the slopes, and some landslide deposits even blocked the river [32,33]. Therefore, the small glacial lake GBTSC GLOF caused a serious disaster, which caused us to reconsider the small-lake induced GLOF hazard after the earthquake.

The aims of this study are: (1) to establish a detailed glacial lake inventory of BKB after the Gorkha earthquake, based on high resolution remote sensing satellite images; (2) to evaluate the GLOF hazard of BKB considering the scenario that outburst floods evolve into debris flows due to erosion and entrainment of loose solids. 

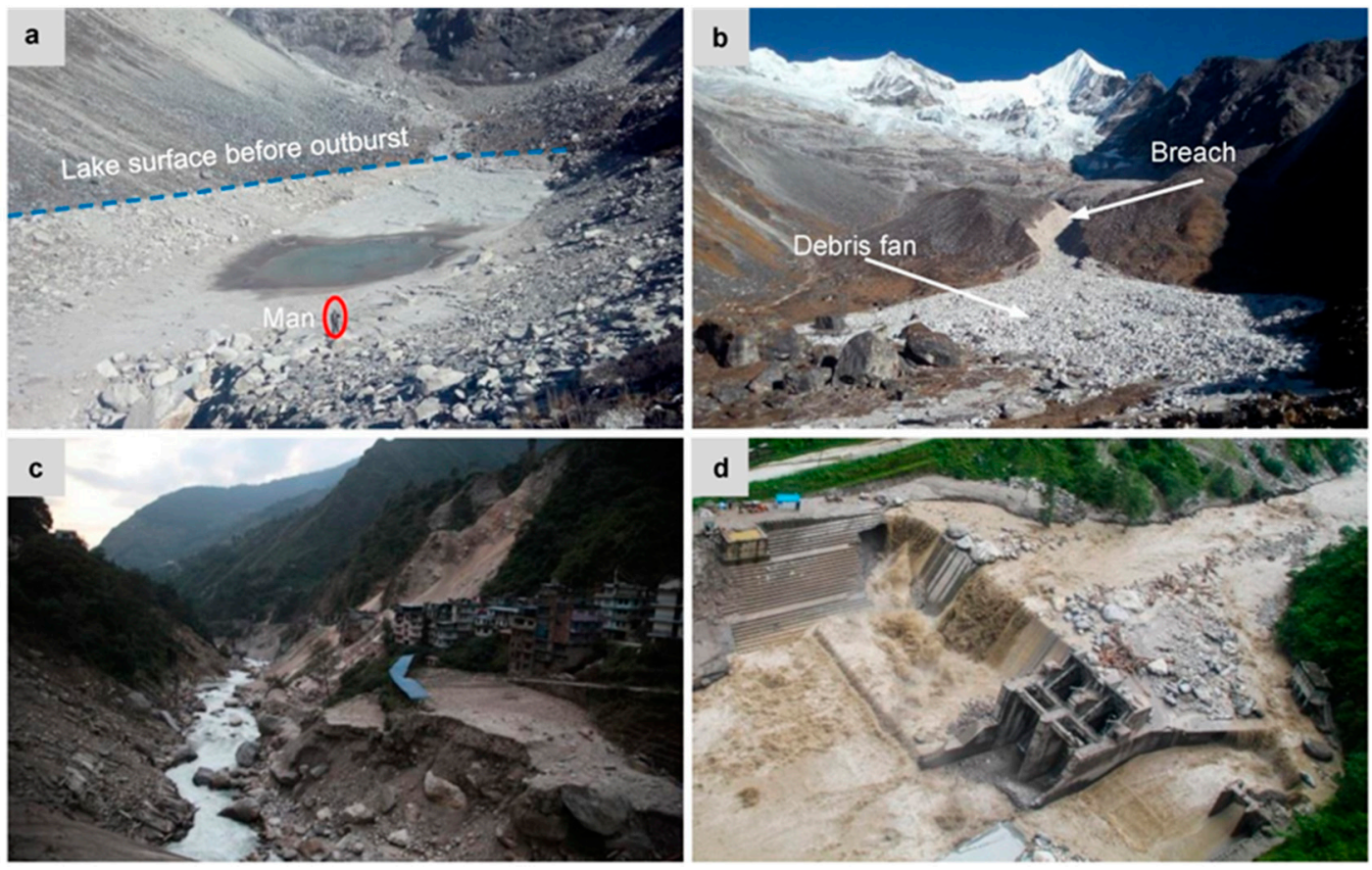

Figure 1. Photographs of Gongbatongshaco (GBTSC) Lake and the glacial lake outburst floods (GLOF) damage caused downstream: (a) GBTSC Lake after outburst, (b) the breach and debris fan in front of the lake, (c) landslides and river bank collapse triggered by GLOF near Friendship Bridge and (d) the destroyed dam of Upper Bhote Koshi Hydroelectric Project in Nepal.

\section{Study Area}

The study site is located in the central Himalayas and covers latitudes $27^{\circ} 37^{\prime}-28^{\circ} 31^{\prime} \mathrm{N}$ and longitudes $85^{\circ} 40^{\prime}-86^{\circ} 20^{\prime} \mathrm{E}$ with an area of $3406 \mathrm{~km}^{2}$ (Figure 2). Bhote Koshi, which is also called Poiqu in China, is a transboundary river with a length of $143 \mathrm{~km}$. It originates in the Bangbulei Mountains in northern Nyalam County, China, flows into Nepal, and at last feeds into the Ganges River. The Araniko Highway, built along the Bhote Koshi Valley, is a key trade and transport route between China and Nepal. Approximately 200,000 people live in the watershed, among which only $2.7 \%$ of them live in China, and the infrastructure in this region is particularly vulnerable [34].

The Bhote Koshi Basin stretches across the Higher Himalaya and Lower Himalaya, and the South Tibetan Detachment System (STDS) and the Main Central Thrust (MCT) pass through it. The basin is strongly affected by seismic activity. According to the statistics of the United States Geological Survey (USGS) earthquake records (http://earthquake.usgs.gov/earthquakes), there were 213 earthquakes (magnitude larger than M 4.5) in the area of $150 \mathrm{~km}^{2}$ around BKB from 1983 to 2016, including a M 8.3 earthquake, three earthquakes larger than M 7.0 and 79 earthquakes equal or larger than M 5.0. The latest large earthquake, M 7.8, on 25 April 2015 and its largest aftershock (M 7.3) on 12 May 2015, produced severe impact in the study area. The epicenter of the major aftershock was only $19 \mathrm{~km}$ southeast of Kodari. The lower part from Zhangzangbo Valley to Dolalghat, which is approximately half of the region, was located in seismic intensity zones VIII and VII, and the upper part was in the VI zone according to the seismic intensity of the Gorkha earthquake provided by the USGS National Earthquake Information Center (Figure 2).

The elevation ranges from the highest peak of Mt. Shishapangma at $8012 \mathrm{~m}$ to the lowest point of $591 \mathrm{~m}$ in Dolalghat, Nepal. Given the large relief, the landforms are different from north to south. In the north and central parts of the basin are alpine regions and gorges, while the valley becomes broader in the south. The climate also varies considerably from south to north. The Himalayan southern slope region of the basin is affected by the Indian monsoon and experiences high precipitation levels. Meanwhile, due to blockage by the Himalayan range, the warm, moist air from the Indian monsoon 
can hardly reach the northern part of the basin. According to monthly data obtained from the Nyalam meteorological station (3810 $\mathrm{m}$ a.s.1.) and the Zhangmu meteorological station (2250 $\mathrm{m}$ a.s.1.), the mean annual temperature ranges from $3.8^{\circ} \mathrm{C}$ to $10.1{ }^{\circ} \mathrm{C}$, and the mean annual precipitation ranges from $643.4 \mathrm{~mm}$ in the north to $2820.6 \mathrm{~mm}$ in the south.

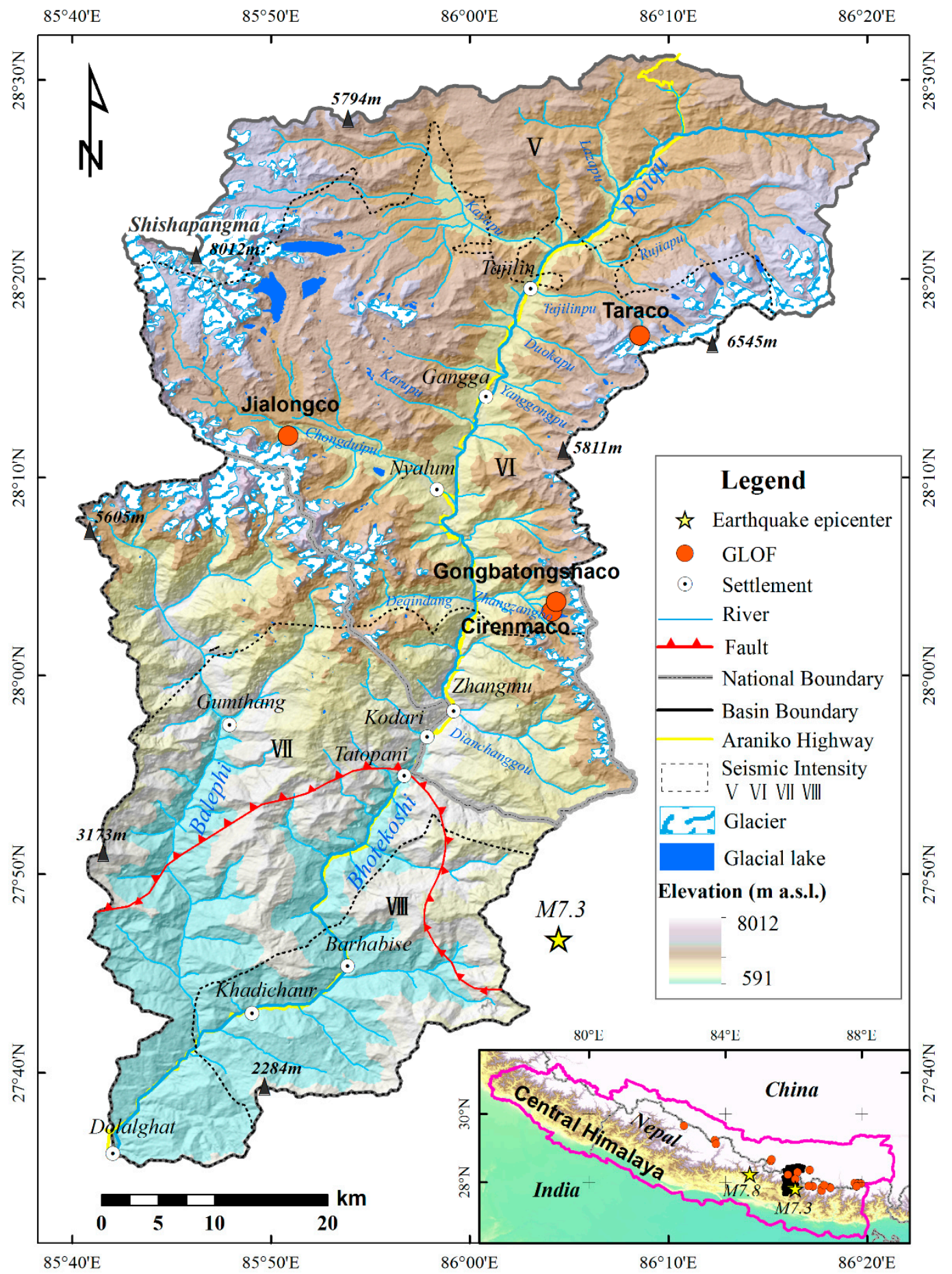

Figure 2. Study area and GLOF events in Bhote Koshi Basin. 


\section{Methods}

\subsection{Glacial Lake and Landslide Inventory Mapping}

Glacial lake and landslide identification were based on GaoFen-1 (GF-1) satellite images. Twenty-two GF-1 images obtained from the China Center for Resources Satellite Data and Application (http://www.cresda.com/CN/) were Level-1A products, with cloud coverage less than 20\% (Table 1). Seven images were used to map glacial lakes and fifteen images were used to map landslides preand post-earthquake. Geometric correction and image sharpening were conducted in ENVI 5.2 before mapping in ArcGIS 10.2. The resolution of pan sharpened images was $2 \mathrm{~m}$. This high-quality imagery available allowed us to recognize glacial lakes as small as $0.01 \mathrm{~km}^{2}$. Manual visual interpretation was used to identify glacial lakes and landslides.

Table 1. GaoFen-1 images used in this study.

\begin{tabular}{ccccc}
\hline Data Usage & Sensor & Product ID & Date & Cloud (\%) \\
\hline & PMS1 & 2056413 & 20 December 2016 & 13 \\
Glacial lake & PMS1 & 2056415 & 20 December 2016 & 4 \\
mapping & PMS1 & 2056414 & 20 December 2016 & 3 \\
& PMS1 & 1929663 & 1 November 2016 & 13 \\
& PMS1 & 1929664 & 1 November 2016 & 16 \\
& PMS1 & 1929665 & 1 November 2016 & 6 \\
\hline & PMS2 & 1524197 & 14 April 2016 & 15 \\
\hline \multirow{5}{*}{ Landslide mapping } & PMS2 & 1242505 & 13 December 2015 & 11 \\
post-earthquake & PMS2 & 1242506 & 13 December 2015 & 1 \\
& PMS2 & 820531 & 22 May 2015 & 1 \\
& PMS1 & 827786 & 23 May 2015 & 3 \\
& PMS2 & 1062062 & 26 May 2015 & 14 \\
& PMS2 & 1062061 & 26 September 2015 & 0 \\
& PMS1 & 1242505 & 13 December 2015 & 11 \\
\hline & PMS2 & 7251892 & 17 December 2015 & 3 \\
\hline \multirow{2}{*}{ pre-earthquake } & PMS2 & 598009 & 11 April 2015 & 0 \\
& PMS2 & 507470 & 19 January 2015 & 12 \\
& PMS3 & 507469 & 9 December 2014 & 1 \\
& PMS1 & 646048 & 22 September 2014 & 19 \\
& PMS1 & 232717 & 22 May 2014 & 2 \\
& PMS1 & 142225 & 30 December 2013 & 9 \\
\hline
\end{tabular}

All glacial lakes were verified and modified against Google Earth to see if there are some misinterpretations of the results due to the effect of terrain shadow. The characteristics and surrounding information of all lakes (larger than $0.01 \mathrm{~km}^{2}$ ) were measured or estimated, aided by Topography Mission digital elevation model (SRTM DEM) $(30 \mathrm{~m})$ and Google Earth. These data compose a complete inventory and provide a basis for identifying dangerous glacial lakes. The inventory of the database consisted of 17 parameters, and some important attributes are explained as follows:

(a) Name: some glacial lakes were annotated according to the topographical map of 1978.

(b) Longitude and latitude: the central location of a glacial lake was calculated automatically in ArcGIS based on WGS84 coordinates.

(c) Elevation ( $m$ a.s.l.): the central elevation of a glacial lake was derived from the DEM.

(d) Dam type: moraine dam, ice dam and bedrock dam, which was specified based on remote sensing images and the topography map (1:100,000; produced in 1978).

(e) Area $\left(\mathrm{km}^{2}\right)$ : the glacial lake surface area was calculated automatically in ArcGIS 10.2, based on UTM projection zone 48 on a WGS84 ellipsoid.

(f) Dam width (m): these values were estimated using Google Earth. 
(g) Volume $\left(\mathrm{m}^{3}\right)$ : each glacial lake's volume was estimated using Equation (1), which was established between lake areas and volumes of lake water based on data from 33 Himalayan glacial lakes measured in the field [34],

$$
V_{\mathrm{gl}}=0.0578 A_{g l}^{1.4683}
$$

where, $A_{g l}$ is glacial lake area.

(h) Estimated freeboard values (1, or 0): the height of the freeboard is difficult to measure by remote sensing but is a crucial parameter that influences dam failure. Here, we estimated whether the height was larger than only a few meters (the value was 1 ) or indeed close to zero (the value was 0) [35], so it is a semiquantitative parameter.

(i) Potential triggering impacts: whether the mass movement around a glacial lake can enter into the lake, such as rockfalls (R), landslides (L), ice and glacier avalanches (IGA), debris flows (DF) or flood from a lake situated upstream (ULF). If there is no mass movement, the value was null. This was identified based on Google Earth and the slope maps derived from the DEM, so it is also a semiquantitative parameter.

(j) Distance to mother glacier $(m)$ : the distance between the back edge of a glacial lake to the mother glacier. If they are in contact, the value was 0; if there is no glacier around the lake, the value was set to null.

(k) Distance to the nearest settlement (m): the drainage distance from the glacial lake dam to the nearest major settlement was measured using ArcGIS 10.2.

(l) Drainage gradient $\left({ }^{\circ}\right)$ : the average drainage gradient was estimated by a DEM-derived drainage map.

In this study, the term landslide refers to mass movement of a slope, including rockfalls, slope failure and soil slides. Most landslides can be easily identified by visual inspection for vegetation loss or deposits. If there is no vegetation in some areas, the morphology needs careful attention. Landslides are classified as pre-earthquake and post-earthquake landslides. The landslide volume $(V)$ was estimated using a power-law landslide area-volume empirical formula (Equation (2)):

$$
V_{s}=\alpha A_{s}^{\gamma}
$$

where $A_{s}$ is landslide area, $\alpha$ and $\gamma$ are empirically calibrated scaling parameters derived from mixed soil and bedrock landslides in the Himalayas; $\alpha$ is 0.257 , and $\gamma$ is 1.36 [36].

\subsection{Glacial Lake Outburst Hazard Assessment}

Glacial lake outburst hazard assessment includes two steps, glacial lake outburst potential assessment and flow magnitude assessment. First, a qualitative method was used to identify glacial lake outburst potential; then, the outburst flow characteristics were determined, flood or debris flow according to loose matter along the flow path and the channel gradient, and then the magnitude at the nearest settlement was calculated. Finally, the GLOF hazard was derived by the glacial lake outburst probability and flow magnitude based on a matrix diagram, which has been widely used in flood, landslide and rock fall hazard assessments [7,37]. GLOF hazards in BKB were divided into four classes: "Very High", "High", "Medium" and "Low". The process of GLOF hazard assessment is summarized in Figure 3. 


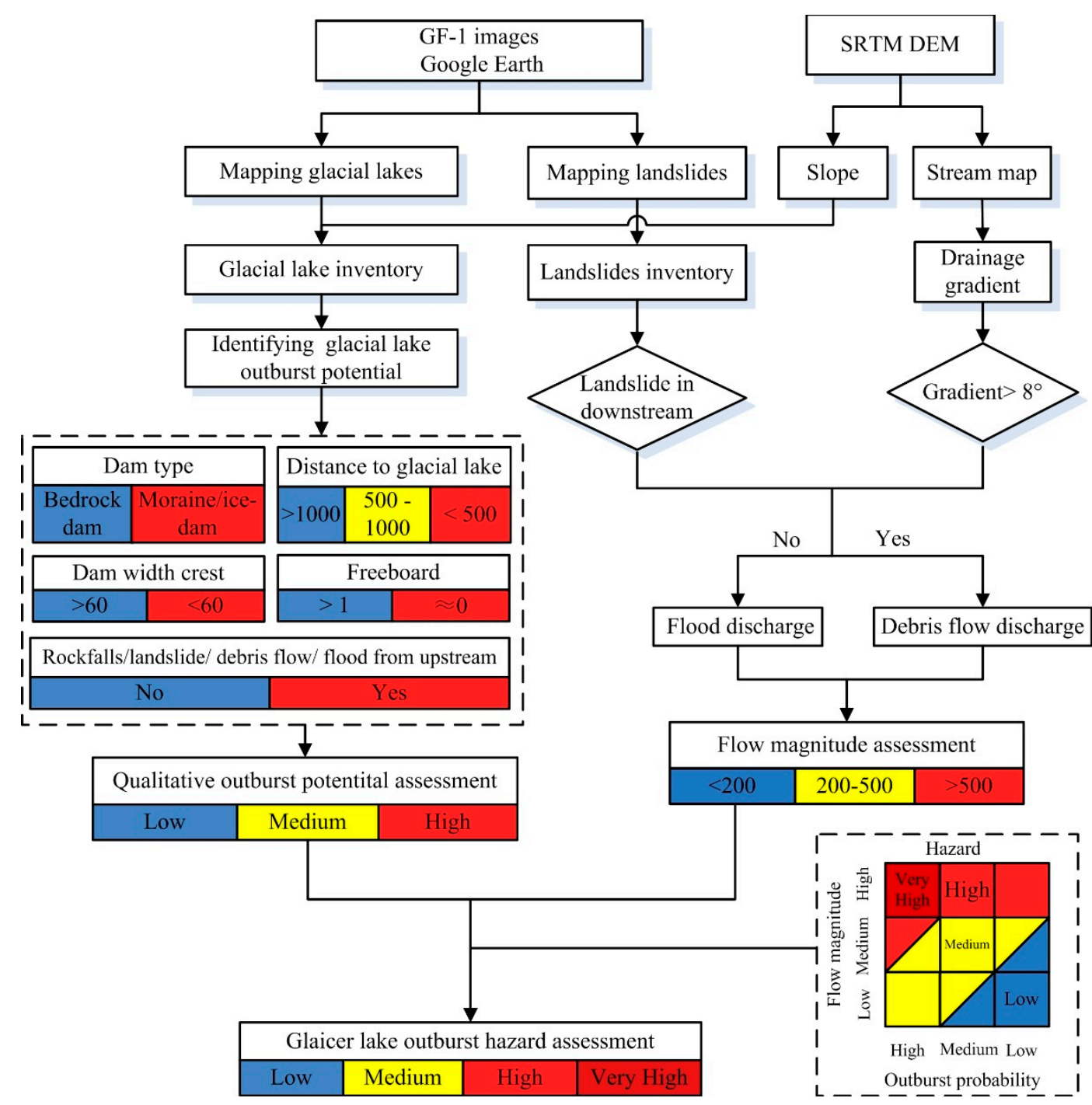

Figure 3. Flow chart illustrating the process used for creating the glacial lake inventory of Bhote Koshi Basin in 2016, classifying glacial lake outburst potential and outburst risk assessment.

\subsubsection{Glacial Lake Outburst Potential Assessment}

Many criteria and schemes, derived from GLOF experiences all around the world, have been proposed to assess and identify potentially dangerous glacial lakes based on GLOF [38-42]. Here, a qualitative assessment method is proposed to identify the potentially dangerous glacial lakes from three criteria. The first one is potential triggering impacts, such as rockfalls, landslides, snow and ice avalanches, debris flows and flood from a lake situated upstream [43]. Such mass movement entering the lakes trigger displacement waves that subsequently overtop and erode the dams is the most common cause of dam failure in the Himalaya $[8,17,44-46]$. Steep glacier surfaces that are in contact with or close to a lake are prone to ice avalanches [47-49]. In addition, steep topography is also likely to cause rockfalls and landslides, and as a glacier retreats, much glacial debris remains, which may start a debris flow under heavy rainfall or intense glacier melting $[8,38,50]$. The second one is dam stability. Studies show most of the GLOF events in the Himalayas are caused by moraineor ice dam failures, and the bedrock dams are the more stable with low outburst probability $[8,51]$. The dam width crest is an indicator for the susceptibility of a dam to fail [52]. The third one is freeboard, which is considered a crucial parameter that influences whether a potential impact wave overtops the dam $[7,49]$. 
Five key indicators were selected to identify glacial lake outburst potential according to the three criteria. These parameters of each glacial lake were easily obtained from the 2016 glacial lake inventory database. The critical values for assessment are given in Figure 3. The key indicator was defined with qualitative probabilities high, medium and low, and considered independently. The overall potential is not the mean of the individual indicators. A high-potential outburst glacial lake must satisfy three criteria that are high, a low-potential lake has two or three low criteria and no high criteria and the rest are medium-potential lakes. Finally, three potential degrees were classified as high, medium and low.

\subsubsection{Flow Magnitude Assessment}

The flow magnitude is highly dependent on the peak discharge at the breach and the channel condition [53]. The peak discharge depends on the lake volume and the breach geometry [38]. For a rapid hazard assessment, complex breach processes and flow behavior are beyond the scope. In this paper, the worst breach scenario was assumed, i.e., a full breach that empties the glacial lake water completely. The maximum discharge $\left(Q_{p}\right)$ was estimated using the empirical formula (Equation (3)):

$$
Q_{p}=2 V_{g l} / t
$$

where $V_{\mathrm{gl}}$ is the glacial lake volume, and $t$ is the drainage duration in seconds, which is assumed to be $1000 \mathrm{~s}$ [54].

The outburst flood peak discharge increases due to erosion and entrained sediments. Thus, we first needed to judge whether an outburst flood would develop into a debris flow. The average channel gradient and unconsolidated deposits along the channel are key factors that affect whether an outburst flood evolves into a debris flow $[13,55]$. Erosion is found to occur where the channel gradients exceed $8^{\circ}$ [38] and abundant unconsolidated deposits are distributed in the channel and on the slopes [56]. Channel gradients were calculated based on drainage maps derived from the DEM. The unconsolidated deposits include moraine deposits, fluvial and glaciofluvial sediments and landslide deposits. The maximum eroded sediment volume per unit channel length varies from ten to hundreds of cubic meters due to local and regional differences in geology, topography and hydrology of torrent catchments $[38,54]$. Therefore, it was hard to set a value certain of sediment depth or volume eroded by flood in different channels or basins. A rough assessment was used to estimate the flow magnitude to the nearest settlement. Flood peak discharge was estimated using an empirical equation (Equation (4)) [57,58]:

$$
Q_{\mathrm{pl}}=\frac{W}{\frac{W}{Q_{p}}+\frac{L}{V K}}
$$

where $Q_{\mathrm{p}}$ is the flood peak discharge $\mathrm{m}^{3} / \mathrm{s} ; W$ is the capacity of the lake, $\mathrm{m}^{3} ; Q_{\mathrm{p}}$ is the peak discharge at the breach, $\mathrm{m}^{3} / \mathrm{s} ; L$ is the distance from the glacial lake dam, $\mathrm{m}$; and $V K$ is an empirical coefficient equal to 3.13 for rivers on plains, 7.15 for mountain rivers and 4.76 for rivers flowing through terrain with intermediate relief [59], which here we set the value as 7.15.

For an outburst debris flow, the water source is the outburst flood. Therefore, the peak discharge of the debris flow consists of outburst flood discharge and soil particle flow. Blocking was not considered here, so the debris flow peak discharge $\left(Q_{\mathrm{df}}\right)$ can be calculated [60]:

$$
Q_{\mathrm{df}}=(1+\varphi) Q_{p l}
$$

where $\varphi$ is the increase coefficient of debris flow peak discharge, which can be calculated by:

$$
\varphi=\left(\gamma_{s}-\gamma_{w}\right) /\left(\gamma_{s}-\gamma_{c}\right)
$$

where $\gamma_{s}$ is the specific gravity of the solid material, $\mathrm{g} / \mathrm{cm}^{3}$, and usually determined as $2.65 \mathrm{~g} / \mathrm{cm}^{3} ; \gamma_{w}$ is the unit weight of water, $\gamma_{w}=1 \mathrm{~g} / \mathrm{cm}^{3} ; \gamma_{c}$ is the unit weight of the debris flow, $\mathrm{g} / \mathrm{cm}^{3}$. Studies show 
glacial lake outburst debris flow in Tibet is usually diluted flow [52], and the density is $1.3-1.8 \mathrm{~g} / \mathrm{cm}^{3}$. For the convenience of calculation, here we set the average value of $\gamma_{c}$ as the density of GBTSC outburst debris flow, $1.55 \mathrm{~g} / \mathrm{cm}^{3}$.

According to Chinese debris flow prevention and control standards (DZT-0220-2006), a peak flow discharge of more than $200 \mathrm{~m}^{3} / \mathrm{s}$ is defined as a large hazard. However, the scale of a glacial outburst flood/debris flow is usually larger than that of a rainfall-triggered debris flow [16]. Therefore, in this paper, three flow magnitude classes were established: flow discharge $<200 \mathrm{~m}^{3} / \mathrm{s}$ (low), 200-500 m³ $/ \mathrm{s}$ (medium) and $>500 \mathrm{~m}^{3} / \mathrm{s}$ (high). Finally, the GLOF hazard was derived by the glacial lake outburst probability and flow magnitude based on a matrix diagram, which has been widely used in flood, landslide and rock falls hazard assessments [7,37]. GLOF hazards in BKB are divided into four classes: "Very High", "High", “Medium" and "Low".

\section{Results}

\subsection{Glacial Lake Inventory}

A total of 122 glacial lakes larger than $0.01 \mathrm{~km}^{2}$ with an area of $20.38 \mathrm{~km}^{2}$ were identified based on the GF-1 images from 2016 (see Supplementary Materials). According to the dam type, 84 moraine-dammed lakes with a total area of $16.87 \mathrm{~km}^{2}$ accounts for the largest number and area of all lakes. These moraine-dammed lakes are mainly distributed at 5100-5400 $\mathrm{m}$ a.s.l. There are 25 bedrock-dammed lakes that account for $15.3 \%$ of the area of all lakes. The average area of a bedrock-dammed lake is $0.12 \mathrm{~km}^{2}$, and are mainly distributed at $4100-4700 \mathrm{~m}$ a.s.l. The ice-dammed lakes are the least and smallest, occupying $10.7 \%$ and $1.9 \%$ of the total number and area. The ice-dammed lakes consist of tiny and small lakes, with a mean area of $0.03 \mathrm{~km}^{2}$, mainly distributed at 5000-5200 m a.s.l. (Figure 4a).
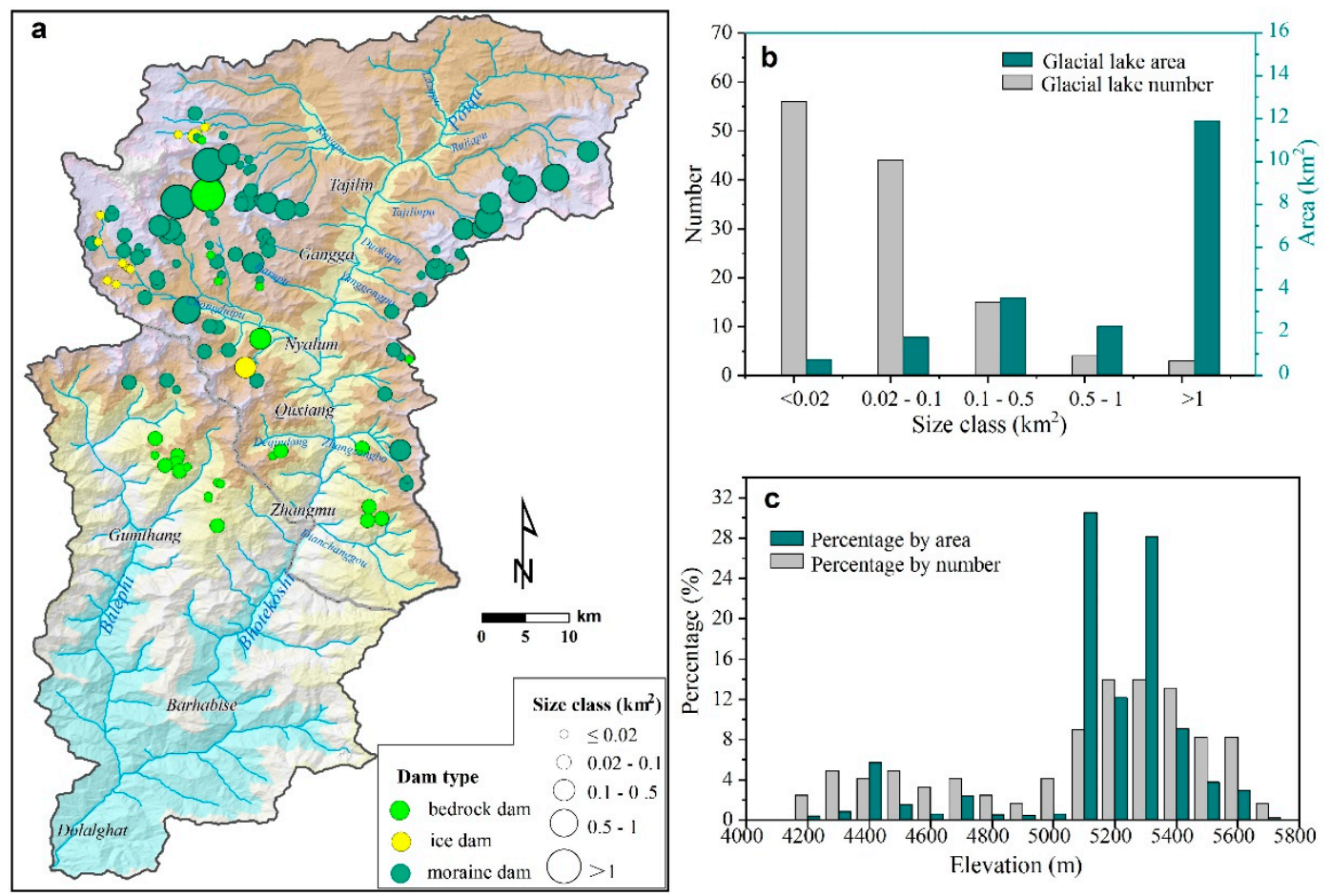

Figure 4. Characteristics of glacial lakes in 2016. (a) Glacial lakes distribution of different dam type and size class, (b) the number and area variation in size classes and (c) the percentage of number and area at different elevations.

As the area of glacial lakes vary greatly, from 0.01 to $5.29 \mathrm{~km}^{2}$, we classify them into five size classes: tiny $\left(\mathrm{A} \leq 0.02 \mathrm{~km}^{2}\right)$, small $\left(0.02<\mathrm{A} \leq 0.1 \mathrm{~km}^{2}\right)$, medium $\left(0.1<\mathrm{A} \leq 0.5 \mathrm{~km}^{2}\right)$, large $\left(0.5<\mathrm{A} \leq 1 \mathrm{~km}^{2}\right)$ and giant $\left(\mathrm{A}>1 \mathrm{~km}^{2}\right)$. The percentage of numbers and areas for each size class are shown in Figure $4 \mathrm{~b}$. 
The main size class of a glacial lake is tiny, accounting for $45.9 \%(n=56)$ of the total number, and small glacial lakes account for approximately $36.1 \%(n=44)$. The total area of tiny and small lakes is $12.4 \%$. Four glacial lakes are large, and three are giant lakes, occupying $69.7 \%$ of the total area. Tha mean value of lake area is $0.17 \mathrm{~km}^{2}$, and the largest glacial lake is Galongco, with a surface area of $5.29 \mathrm{~km}^{2}$.

The glacial lakes are distributed at elevations ranging from 4100 to $5750 \mathrm{~m}$ a.s.l. and are separated into different elevation classes every $100 \mathrm{~m}$ (Figure 4c). Most glacial lakes are located at elevations of $5000-5600 \mathrm{~m}$ a.s.1., accounting for $66.4 \%$ and $86.6 \%$ of the total number and area, respectively. Approximately $27.9 \%$ of glacial lakes are located below $5000 \mathrm{~m}$ a.s.l. and are evenly distributed in each elevation class with an average $3.5 \%$ by number. Approximately $13.9 \%$ of glacial lakes are distributed from $5200-5300 \mathrm{~m}$ a.s.1. and account for $28.1 \%$ of the area of all lakes. It is noticeable that the largest percentage by area is distributed at 5000-5100, which accounts for $30.55 \%$.

\subsection{Glacial Lake Outburst Flood Hazard}

The glacial lake outburst potential assessment results show that 19 glacial lakes have high outburst potential, in which all of these lakes are moraine-dammed and ice/glacier avalanche is the main potential triggering impact; 51 are medium risk, in which two are ice-dammed and nine are bedrock-dammed, and 42 lakes with an area less than $0.1 \mathrm{~km}^{2} ; 52$ glacial lakes are low, in which 11 are ice-dammed and 16 are bedrock-dammed (Figure 5a). It is noticeable that 11 out of 19 high outburst potential lakes have an area less than $0.1 \mathrm{~km}^{2}$, and the one bedrock-dammed lake, Gongco, with an area of $2.9 \mathrm{~km}^{2}$, has low outburst potential.
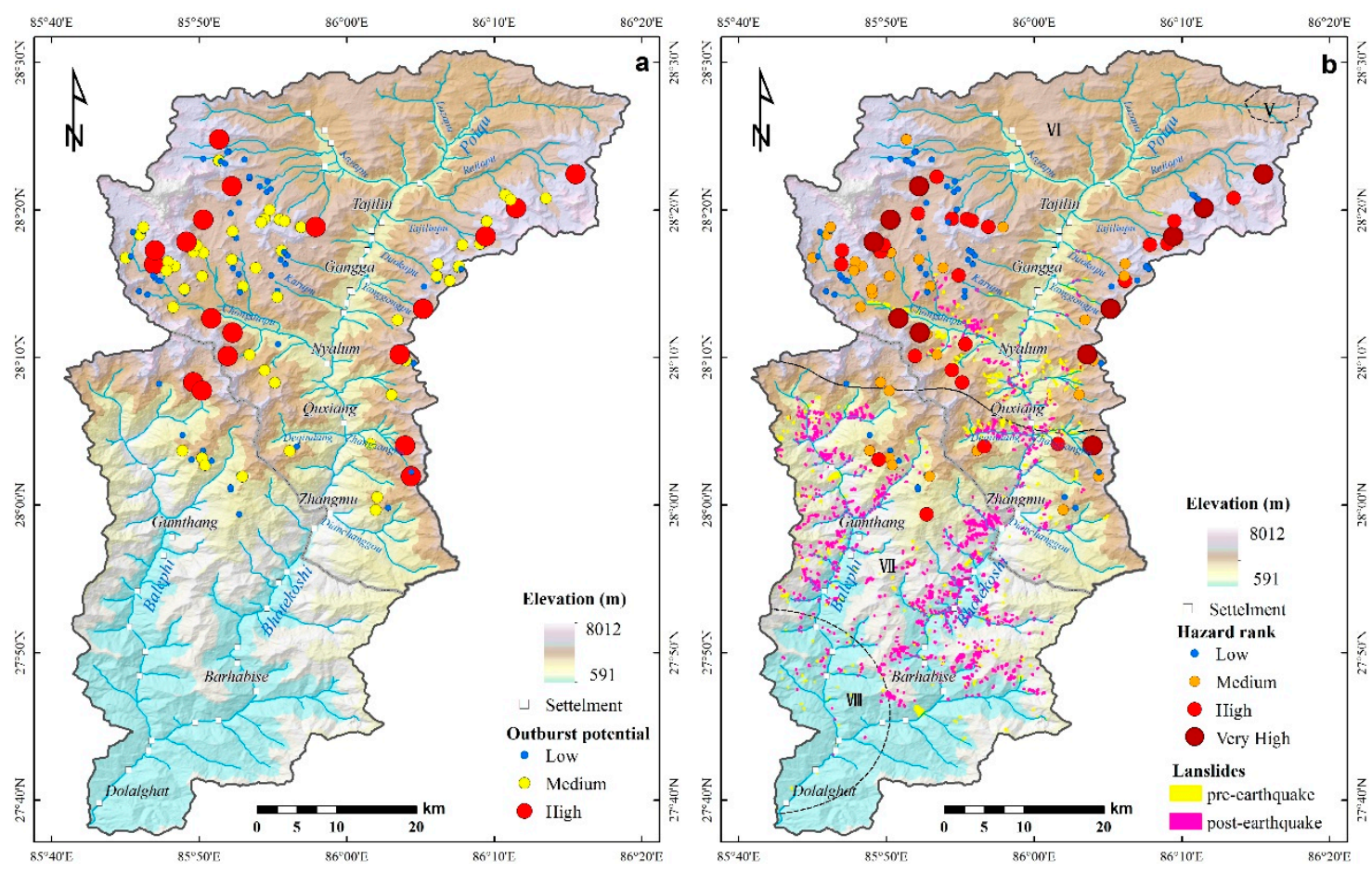

Figure 5. (a) Glacial lake outburst potential and (b) glacial lake outburst flow/debris flow hazard assessed in this study, considering landslide deposit distribution.

In this study, 1670 landslides with a total area of $18.70 \mathrm{~km}^{2}$ were identified, in which 1183 , with an area of $12.18 \mathrm{~km}^{2}$, were triggered by the Gorkha earthquake (Figure $5 \mathrm{~b}$ ). These post-earthquake landslides vary in size ranging from $230 \mathrm{~m}^{2}$ to $254,474 \mathrm{~m}^{2}$. Most of the landslides are distributed in the middle and southern parts of the basin, and a large number of Gorkha earthquake-triggered landslides are concentrated in the VII region of seismic intensity. A lot of landslides were distributed in the sub-basins such as Gumthang, Deqingdang, Chongduipu, Zhangzangbo and Dianchangchanggou. Large landslides reach channels, and some small landslides are mostly located on steep slopes 
disconnected from a river channel. The other 487 landslides occurred before the Gorkha earthquake and have an area of $6.51 \mathrm{~km}^{2}$. The largest mapped landslide that occurred before the earthquake is $0.81 \mathrm{~km}^{2}$. The total landslide deposit volume is estimated at $91.67 \times 10^{6} \mathrm{~m}^{3}$ before the earthquake, and the volume increased to $216.03 \times 10^{6} \mathrm{~m}^{3}$ after the earthquake. Considering landslide distribution, 73 glacial lake outburst floods are highly prone to debris flow, which will increase the magnitude.

According to the glacial lake outburst potential and flow magnitude, GLOF hazard assessment results are shown in Table 2 and Figure 5. Eleven glacial lakes are identified with very high hazard, among which seven could evolve into debris flows. Twenty-four glacial lakes are high hazard, among which 11 could evolve into debris flows. Thirty-two glacial lakes are identified with medium hazard; the other 55 glacial lakes are considered to have low to no hazard to downstream areas. Four very high-hazard glacial lakes are located in the Chongduipu gully, which presents a large threat to Nyalam County, especially the giant glacial lake Galongcuo that could generate a peak flow discharge of about $224,449 \mathrm{~m}^{3} / \mathrm{s}$. Both Jialongcuo and Cirenmacuo have burst out twice before, and are also identified as very high hazard due to high freeboards and hanging glaciers behind the lakes. Eight glacial lakes with low-outburst probability but high-magnitude flow are considered to have high hazard. Among these lakes, Gongcuo and Darecuo are bedrock-dammed lakes and have no potential triggering impacts around the lakes, so they are considered to have a low probability of outburst. However, because of their large volumes, the outburst flows are assumed to be high. $63 \%(n=22)$ of the very high and high glacial lakes' areas are larger than $0.1 \mathrm{~km}^{2}$, and their peak flow discharges were larger than $1000 \mathrm{~m}^{3} / \mathrm{s}$. Ten small glacial lakes (area $<0.1 \mathrm{~km}^{2}$ ) identified as high hazard. Three small glacial lakes, No. 16 (area $0.09 \mathrm{~km}^{2}$ ), No. 18 (area $0.05 \mathrm{~km}^{2}$ ) and No. 81 (Nongjue, area $0.07 \mathrm{~km}^{2}$ ), are considered very high hazard for they may cause peak debris flow discharges of $1118 \mathrm{~m}^{3} / \mathrm{s}, 597 \mathrm{~m}^{3} / \mathrm{s}$ and $994 \mathrm{~m}^{3} / \mathrm{s}$ at the nearest settlement, respectively. 
Table 2. Very high and high hazard glacial lakes.

\begin{tabular}{|c|c|c|c|c|c|c|c|c|c|c|c|}
\hline Id & Name & $\begin{array}{l}\text { Longitude } \\
\left.\quad{ }^{\circ}\right)\end{array}$ & $\begin{array}{c}\text { Latitude } \\
\left({ }^{\circ}\right)\end{array}$ & $\begin{array}{l}\text { Elevation } \\
\text { (m) }\end{array}$ & Dam Type & Area $\left(\mathrm{km}^{2}\right)$ & $\mathrm{Q}_{\mathrm{pl}}\left(\mathrm{m}^{3}\right)$ & $Q_{d f}\left(m^{3}\right)$ & $\begin{array}{c}\text { Probablity of } \\
\text { Outburst }\end{array}$ & $\begin{array}{c}\text { Flow } \\
\text { Magnitude }\end{array}$ & Hazard \\
\hline 1 & Qiezelaco & 86.26 & 28.37 & 5532 & moraine & 0.26 & 1967 & & High & High & Very High \\
\hline 3 & Cawuqudenco & 86.19 & 28.34 & 5423 & moraine & 0.55 & 6666 & & High & High & Very High \\
\hline 7 & Paquco & 86.16 & 28.30 & 5307 & moraine & 0.58 & 7950 & & High & High & Very High \\
\hline 16 & & 86.09 & 28.22 & 5178 & moraine & 0.09 & 726 & 1814 & High & High & Very High \\
\hline 18 & & 86.06 & 28.17 & 5194 & moraine & 0.05 & 239 & 597 & High & High & Very High \\
\hline 22 & Cirenmaco & 86.07 & 28.07 & 4633 & moraine & 0.34 & 5087 & 12,717 & High & High & Very High \\
\hline 34 & Gangxico & 85.87 & 28.36 & 5212 & moraine & 4.52 & 172,879 & & High & High & Very High \\
\hline 61 & Galongco & 85.84 & 28.32 & 5077 & moraine & 5.29 & 145,746 & 364,365 & High & High & Very High \\
\hline 62 & & 85.82 & 28.30 & 5093 & moraine & 0.27 & 1832 & 4580 & High & High & Very High \\
\hline 80 & Jialongco & 85.85 & 28.21 & 4380 & moraine & 0.63 & 8336 & 20,840 & High & High & Very High \\
\hline 81 & Nongjue & 85.87 & 28.19 & 4628 & moraine & 0.07 & 398 & 994 & High & High & Very High \\
\hline 2 & Youmojiaco & 86.23 & 28.35 & 5337 & moraine & 0.55 & 4881 & & Medium & High & High \\
\hline 6 & Gangpuco & 86.16 & 28.32 & 5543 & moraine & 0.22 & 2355 & & Medium & High & High \\
\hline 8 & Southhu & 86.15 & 28.30 & 5343 & moraine & 0.17 & 1227 & & Medium & High & High \\
\hline 9 & Taracuo & 86.13 & 28.29 & 5257 & moraine & 0.23 & 2186 & & Medium & High & High \\
\hline 10 & Tuzhuocuo & 86.10 & 28.25 & 5201 & moraine & 0.15 & 1309 & 3272 & Low & High & High \\
\hline 23 & & 86.03 & 28.07 & 4486 & bedrock & 0.03 & 257 & 642 & Medium & High & High \\
\hline 32 & Yinreco & 85.89 & 28.37 & 5245 & moraine & 0.28 & 2878 & & Low & High & High \\
\hline 40 & Mabiya & 85.91 & 28.32 & 5384 & moraine & 0.14 & 931 & & Medium & High & High \\
\hline 42 & & 85.92 & 28.32 & 5345 & moraine & 0.08 & 504 & & Medium & High & High \\
\hline 43 & Mulaco & 85.93 & 28.32 & 5306 & moraine & 0.11 & 760 & & Medium & High & High \\
\hline 44 & Xiahu & 85.95 & 28.31 & 5232 & moraine & 0.31 & 3352 & & Medium & High & High \\
\hline 51 & Cuonongjue & 85.92 & 28.26 & 5095 & moraine & 0.23 & 2353 & & Low & High & High \\
\hline 63 & & 85.83 & 28.29 & 5013 & moraine & 0.26 & 1863 & 4658 & Medium & High & High \\
\hline 64 & & 85.83 & 28.29 & 5050 & moraine & 0.06 & 204 & 511 & Medium & High & High \\
\hline 70 & & 85.78 & 28.29 & 5418 & moraine & 0.05 & 130 & 324 & High & Medium & High \\
\hline 72 & & 85.78 & 28.27 & 5309 & moraine & 0.07 & 184 & 459 & High & Medium & High \\
\hline 83 & & 85.87 & 28.17 & 4712 & moraine & 0.04 & 125 & 312 & High & Medium & High \\
\hline 84 & Daroco & 85.92 & 28.18 & 4366 & bedrock & 0.48 & 10,966 & 27,414 & Low & High & High \\
\hline 85 & & 85.91 & 28.15 & 4486 & ice & 0.20 & 2468 & & Medium & High & High \\
\hline 86 & & 85.92 & 28.14 & 4871 & moraine & 0.09 & 597 & & Medium & High & High \\
\hline 88 & & 85.94 & 28.07 & 4524 & bedrock & 0.06 & 391 & 977 & Low & High & High \\
\hline 89 & Bhairab Kunda & 85.88 & 27.99 & 4102 & bedrock & 0.06 & 304 & 760 & Low & High & High \\
\hline 102 & & 85.83 & 28.05 & 4250 & bedrock & 0.07 & 210 & 524 & Low & High & High \\
\hline 103 & Gongco & 85.87 & 28.33 & 5113 & bedrock & 2.09 & 28936 & & Low & High & High \\
\hline
\end{tabular}

Note: $Q_{\mathrm{pl}}$ is the flood peak discharge at the nearest settlement and $Q_{\mathrm{df}}$ is the debris flow peak discharge at the nearest settlement. 


\section{Discussion}

\subsection{Glacial Lake Inventory}

The new 2016 glacial lake inventory indicates that BKB is highly developed glacial lakes. Glacial lake inventory studies have also been conducted in other regions along the Himalayas [61-64]. Glacial lake studies in the Himalayas show that the greatest numbers and areas of glacial lakes are distributed in the central Himalaya $[2,7,9,10,62,65]$. To compare the glacial lakes and GLOF of BKB with other regions throughout the central Himalayas, the Gyirong River Basin (GRB), which is next to BKB with a similar area was selected and the glacial lake density (glacial lake number/basin area) and lake area per basin area (total glacial lake area/basin area) were calculated (Table 3 ). The results show that the glacial lake density of BKB is four times that of the central Himalayas and the lake area per basin area is four times that of GRB. The basin area of GRB is larger than BKB, and the glacial lakes density is similar, while the lake per basin area varies greatly. This is due to more large and giant lakes in BKB. According to the statistics, the largest lake is less than $0.5 \mathrm{~km}^{2}$ in GRB, while there are seven lakes larger than $0.5 \mathrm{~km}^{2}$ with the largest being $5.29 \mathrm{~km}^{2}$ in BKB. Studies show the glacial lake expansion rate reaching $0.26 \mathrm{~km}^{2} /$ year in Poiqu [66], while the rate of GRB is $0.09 \mathrm{~km}^{2} /$ year [63]. Glacial lake expansion is the result of glacier retreating response to climate change. That means BKB is more sensitive to climate change than GRB.

Table 3. Comparison of glacial lake and glacial lake outburst flood among Bhote Koshi Basin, Gyirong River Basin and Central Himalaya.

\begin{tabular}{cccccc}
\hline Region & $\begin{array}{c}\text { Basin Area } \\
\left(\mathbf{k m}^{\mathbf{2}}\right)\end{array}$ & $\begin{array}{c}\text { Number of } \\
\text { Glacial Lakes }\end{array}$ & $\begin{array}{c}\text { Glacial Lake } \\
\text { Area (km } \mathbf{~})\end{array}$ & $\begin{array}{c}\text { Glacial Lake } \\
\text { Density }\end{array}$ & $\begin{array}{c}\text { Lake per Basin } \\
\text { Area }\end{array}$ \\
\hline Bhote Koshi Basin & 3406 & 122 & 20.38 & 0.04 & 0.0060 \\
Gyirong River Basin [63] & 4640 & 148 & 7.12 & 0.03 & 0.0015 \\
Central Himalaya [2] & 280,000 & 1943 & 203.7 & 0.01 & 0.0007 \\
\hline
\end{tabular}

The analysis of multitemporal and high-resolution remote sensing images during the compilation of the glacial lake inventories provided a good opportunity to identify previously unreported GLOF events $[67,68]$. Six unreported glacial lake outburst events were found when we mapped glacial lakes from GF-1 and Google Earth. These glacial lakes have retained typical outburst geomorphic and sedimentological features, such as V-shaped breaches, debris fans and subsequent devastated channels (Figure 6). All of them were moraine-dammed lakes, and their surface areas are $0.01-0.11 \mathrm{~km}^{2}$. Two glacial lakes (Figure 6a,b) are located in Keyapu Valley and the other four (Figure 6c-f) are in Chongduipu Valley. All glacial lakes except No. 31 are fed by glaciers, and the distances to the glaciers are less than $500 \mathrm{~m}$. The V-shaped breach and debris fan of glacial lake No. 86 is the largest, and its mother glacier is thick and hangs behind the lake. The surface area of the glacial lake is $0.09 \mathrm{~km}^{2}$ and the freeboard is much more than one. The rest of the outburst events were small scale and seemed to cause no downstream damage since no erosion was observed in downstream channels. The outburst flood formed a deposition fan at the intersection with the main channel, such as glacial lake No. 31, where the outburst deposition blocked the channel and formed a small lake. Some vegetation has covered the debris fan (glacial lake No. 86) and deposition fan (glacial lake No. 81). It shows that the glacial lake outburst occurred a long time ago. However, the outburst time (year) cannot be determined because of the lack of long-term and high-quality (low cloud cover or high-resolution) data. We traced theses lakes on Google Earth images, and it shows that outburst signs have existed since 1984. As we documented in the literature, we found there was a GLOF event in 1955 in Nyalam, but the record did not mention which lake burst out [30]. Four glacial lakes (Figure 6c-f) are located in the Chongduipu Basin upstream of Nyalam County. As we cannot be sure of the exact outburst time, the outburst magnitudes can be estimated only through debris fans. Glacial lake No. 86 had the largest outburst magnitude with a debris fan area of approximately $252,808 \mathrm{~m}^{2}$, and the gully downstream is highly eroded. This lake may have caused damage in downstream areas. The other three glacial lake deposits 
are found at the intersections with the main channel (Chongduipu), which means their outburst floods did not propagate downstream. Therefore, we conclude that the GLOF event in 1955 was caused by glacial lake No. 86 .
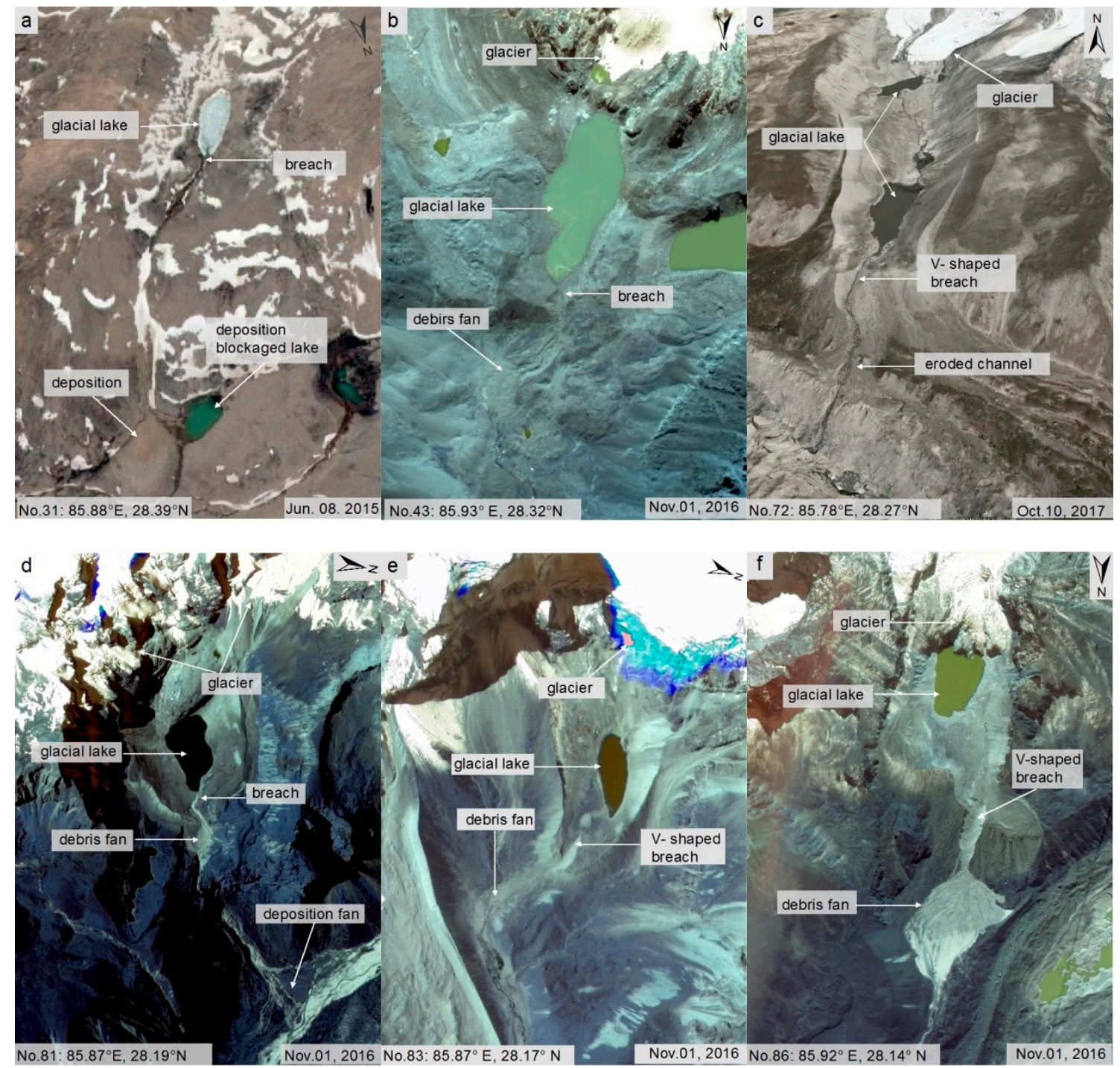

Figure 6. Unreported glacial lake outburst flood events were identified based on Google Earth images $(\mathbf{a}, \mathbf{c})$ and GaoFen-1 (GF-1) images $(\mathbf{b}, \mathbf{d}-\mathbf{f})$ in the Bhote Koshi Basin.

The six undocumented outburst events found show that high-resolution remote sensing images make it possible to trace minor GLOF events that were unreported because of difficult access or few people living in high mountain regions. It also proves that the GLOF frequency is high in BKB. Other unknown and unpublished GLOF have also been found in Bhutan, Nepal and other parts of the Himalayas, based on long-time-series remote sensing data that show glacial lake changes (disappearance or abrupt shrinkage) and typical topographic features, such as exposed debris fans and sediment tails in downstream river channels $[9,17,18]$. A database of past GLOF events as complete as possible is essential for robust and reliable GLOF hazard assessment [69]. The gradually improving GLOF inventory helps us better understand the mechanism of GLOF and to do hazard assessment. 


\subsection{Glacial Lake Outburst Hazard}

A GLOF is a complex process, and the hazard magnitude is determined by the outburst water volume and flood routing $[8,22,38]$. The outburst water volume is mainly related to the glacial lake volume [54,70]. Since the depth of a glacial lake is hard to acquire by remote sensing data and investigation, the surface area of the lake becomes an important indicator for assessing lake volume and hazard. In previous GLOF hazard assessment studies, glacial lakes smaller than $0.1 \mathrm{~km}^{2}$ were assumed not to pose a hazard potential relevant to downstream locations [47]. Khanal et al. [34] identified 10 critical lakes in the BKB, and all of them are larger than $0.2 \mathrm{~km}^{2}$. Indeed, small glacial lake outbursts can cause damage to downstream locations. According to the inventory of historical glacial lake outburst floods in the Himalayas, small GLOF, such as Zanaco, Geiqu and Choradari Lakes with areas smaller than $0.1 \mathrm{~km}^{2}$, damaged downstream roads and villages [9]. On one hand, a small outburst can create a much larger outburst from another lake located downstream, for examples, the reach of GLOF from lakes Artesoncocha and Chacrucocha [43,67]. On the other hand, a small glacial lake outburst flood can transform into debris flows due to downstream sediment entrainment. For example, a small ice-dammed lake outburst in 2009 (area of 34,000 $\mathrm{m}^{2}$ ) at Keara in the Andes caused damage $10 \mathrm{~km}$ downstream [41].

During the flood routing, landslides on the slopes enter the flood, transforming the flood into debris flows and greatly increasing the discharge, volume and impact. Ignoring the earthquake-induced landslides would underestimate the basin's GLOF hazard. If we do not consider landslides triggered by earthquakes transforming the glacial lake outburst floods into debris flows in the BKB, only nine glacial lakes are identified as having very high hazard, 16 are at high hazard, 12 are at medium hazard and 85 are at low hazard. The hazards rank of two very high hazard small glacial lakes, eight high hazard lakes and 20 medium hazard lakes, accounting for $24.6 \%$ of the total lakes, would be decreased. It leads to the GLOF hazard of BKB greatly underestimated.

In this study, the GLOF caused by GBTSC on 25 July 2016 is a good example. GBTSC is located in the Zhangzangbo Valley on the right bank of the Poiqu River, and the average gradient is $182 \%$ o (Figure $7 \mathrm{~b}$ ). This lake was tiny; the surface area before the outburst was $0.01 \mathrm{~km}^{2}$. After the outburst, the lake was almost empty as shown in Figure $7 \mathrm{~b}$. The width of the breach was $27 \mathrm{~m}$, and the depth was $9 \mathrm{~m}$. The peak discharge was $618 \mathrm{~m}^{3} / \mathrm{s}$, and increased to $4019 \mathrm{~m}^{3} / \mathrm{s}$ at the section of the Zhangzangbo Valley mouth (approximately $7.2 \mathrm{~km}$ from the breach), according to the investigation and assessment report written by the Institute of Mountain Hazards and Environment (http://www.imde.ac.cn). The discharge increased by almost eight times because the outburst flood changed to a debris flow. The Zhangzangbo was in the seismic intensity zone VII and intensely impacted by the Gorkha earthquake. Many landslides were triggered along the river, and some landslide deposits blocked the river (Figure $7 \mathrm{c}, \mathrm{d}$ ). The loose mass volume increased to $8.74 \times 10^{6} \mathrm{~m}^{3}$ in Zhangzangbo according to the landslide distribution. These landslide deposits provided rich masses for the debris flow. Once the GLOF occurred, these deposits were easily eroded and entrained, leading the flood to change to a debris flow and amplifying the discharge. Tens of thousands of landslides were triggered by the M 7.8 (Gorkha) and M 7.3 (Dolakha) earthquakes [71,72]. It will take some time to transport these landslide deposits, which accumulated on the slope or in the channel. Thus, in the region affected by strong earthquakes, we must strengthen the monitoring of high-hazard glacial lakes and pay special attention to glacial lake outburst debris flows after an earthquake. 

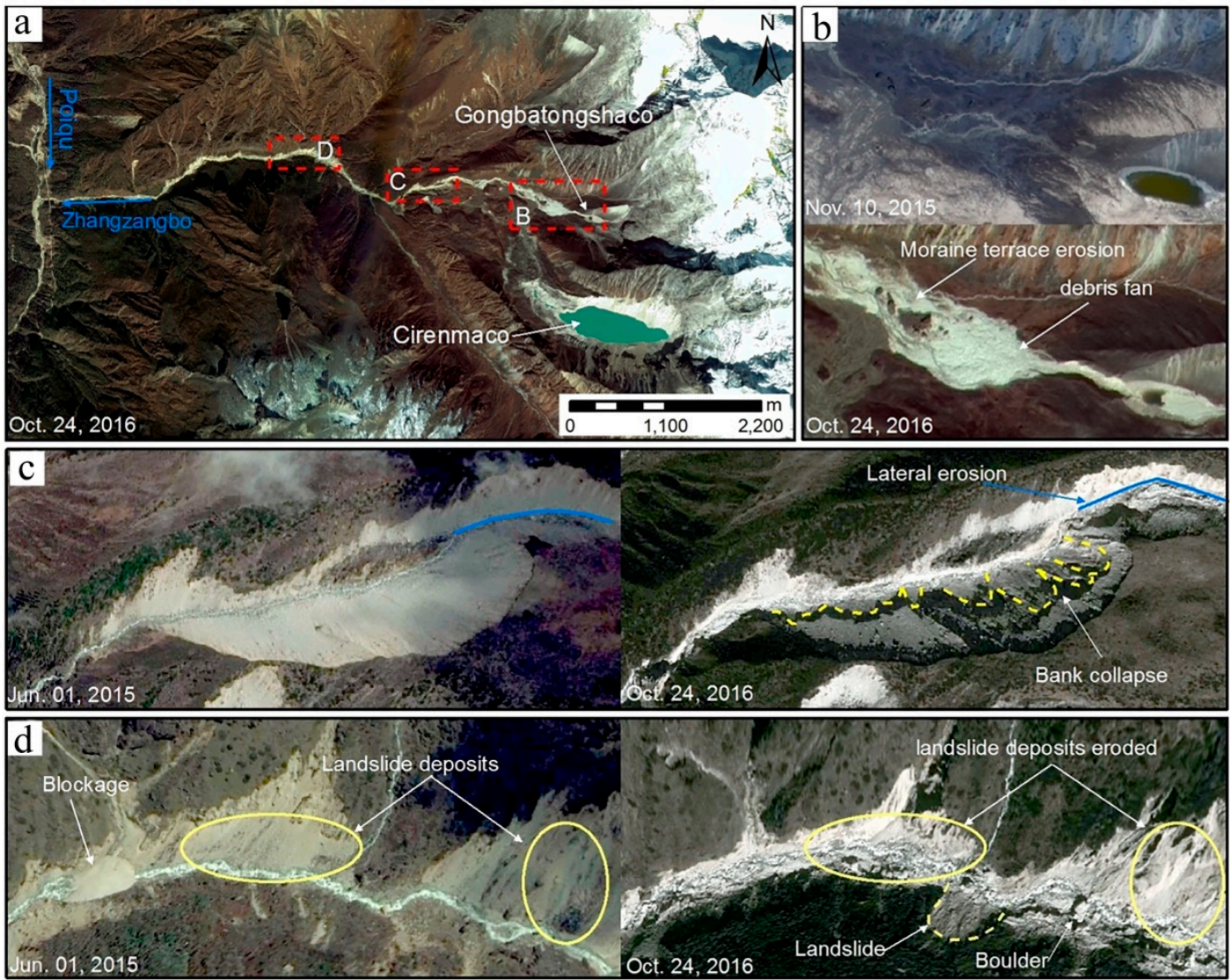

Figure 7. Comparison of channel changes before and after GBTSC GLOF along the Zhangzangbo Valley. (a) The flow path of GBTSC GLOF; (b) GF-1 images showing that the flood left a large debris fan in the front of the lake, and eroded the moraine terrace; (c) lateral erosion and bank collapse in the moraine terrace and the width of channel increased; (d) landslide deposits distributed along the channel and blocked the channel before bursting, while GLOF eroded landslide deposits and triggered bank slump and landslide afterward, causing an increase in channel width. (Note: the 1 June 2015 images of c and $\mathrm{d}$ are from Google Earth, others are GF-1 images).

\section{Conclusions}

In this study a new detailed 2016 inventory of glacial lakes in the BKB was established and six unreported GLOF that occurred before 1984 have been detected with geomorphic outburst evidence based on high-resolution remote sensing images. The BKB is one of the most hotspot small river basins for glacial lakes and GLOF in the central Himalayas. High-resolution remote sensing images are useful for detecting unreported GLOF events in high mountainous regions and sparsely populated regions, which is conducive to improving the GLOF inventory and better assessing GLOF hazard. A rough but more comprehensive method was proposed to assess GLOF hazard, which considers the probability for a flood to develop into a debris flow in the downstream, where large numbers of landslides triggered by earthquake are distributed. The GLOF hazard in BKB increases due to landslide deposits volume, which increased approximately $124.36 \times 10^{6} \mathrm{~m}^{3}$ after the Gorkha earthquake, and 11 glacial lakes are identified as very high hazard, nine are high hazard, 32 are medium hazard and 55 are low hazard. However, about $24.6 \%$ of the all lakes' hazards would be underestimated without earthquake-induced landslides, in which most of them are small glacial lakes. Therefore, for regional GLOF hazard assessment, small glacial lakes should not be overlooked for landslide deposit entrainment along a flood route and flood eroding channel bed would increase the peak discharge, especially in earthquake affected areas where large numbers of landslides were triggered. We suggest 
that more attention should be paid to the very high and high-hazard glacial lakes and to improving the engineering security standard for defending against flood hazards downstream of BKB.

Supplementary Materials: The following are available online at http://www.mdpi.com/2073-4441/12/2/464/s1. Table S1: glacial lake inventory of Bhote Koshi.

Author Contributions: N.C. and M.L. conceived the original ideas and drafted the original manuscript. Y.Z. and M.D. carried out field investigation and data collection. N.C. and M.L. revised the original manuscript. All authors have read and agreed to the published version of the manuscript.

Funding: This research was funded by National Natural Science Foundation of China (Grant NOs. 41671112 and 41861134008) and the 135 Strategic Program of the IMHE, CAS (Grant NO. SDS-135-1705).

Conflicts of Interest: The authors declare there no conflict of interest.

\section{References}

1. Bolch, T.; Stoffel, M. The State and Fate of Himalayan Glaciers. Science 2012, 336, 310-314. [CrossRef] [PubMed]

2. Nie, Y.; Sheng, Y.; Liu, Q.; Liu, L.; Liu, S.; Zhang, Y.; Song, C. A regional-scale assessment of Himalayan glacial lake changes using satellite observations from 1990 to 2015. Remote Sens. Environ. 2017, 189, 1-13. [CrossRef]

3. Kang, S.; Xu, Y.; You, Q.; Flügel, W.-A.; Pepin, N.; Yao, T. Review of climate and cryospheric change in the Tibetan Plateau. Environ. Res. Lett. 2010, 5, 015101. [CrossRef]

4. Song, C.; Sheng, Y.; Wang, J.; Ke, L.; Madson, A.; Nie, Y. Heterogeneous glacial lake changes and links of lake expansions to the rapid thinning of adjacent glacier termini in the Himalayas. Geomorphology 2016, 280. [CrossRef]

5. Harrison, S.; Kargel, J.S.; Huggel, C.; Reynolds, J.M.; Vilímek, V. Climate change and the global pattern of moraine-dammed glacial lake outburst floods. Cryosphere 2018, 12, 1195-1209. [CrossRef]

6. Cenderelli, D.A.; Wohl, E.E. Peak discharge estimates of glacial-lake outburst floods and "normal" climatic floods in the Mount Everest region, Nepal. Geomo 2001, 40, 57-90. [CrossRef]

7. Worni, R.; Huggel, C.; Stoffel, M. Glacial lakes in the Indian Himalayas-From an area-wide glacial lake inventory to on-site and modeling based risk assessment of critical glacial lakes. Sci. Total Environ. 2013, 468, S71-S84. [CrossRef]

8. Richardson, S.D.; Reynolds, J.M. An overview of glacial hazards in the Himalayas. Quat. Int. 2000, 65-66, 31-47. [CrossRef]

9. Nie, Y.; Liu, Q.; Wang, J.; Zhang, Y.; Sheng, Y.; Liu, S. An inventory of historical glacial lake outburst floods in the Himalayas based on remote sensing observations and geomorphological analysis. Geomorphology 2018, 308, 91-106. [CrossRef]

10. Yamada, T.; Sharma, C. Glacier lakes and outburst floods in the Nepal Himalaya. IAHS Publ. Publ. Int. Assoc. Hydrol. Sci. 1993, 218, 319-330.

11. Kattelmann, R. Glacial lake outburst floods in the Nepal Himalaya: A manageable hazard? Nat. Hazards 2003, 28, 145-154. [CrossRef]

12. Falátková, K. Temporal analysis of GLOFs in high-mountain regions of Asia and assessment of their causes. Acta Univ. Carol. Geogr. Univ. Karlov. 2016, 51, 145-154. [CrossRef]

13. Worni, R.; Huggel, C.; Clague, J.J.; Schaub, Y.; Stoffel, M. Coupling glacial lake impact, dam breach, and flood processes: A modeling perspective. Geomo 2014, 224, 161-176. [CrossRef]

14. ICIMOD. Glacial Lakes and Glacial Lake Outburst Floods in Nepal; International Centre for Integrated Mountain Development: Kathmandu, Nepal, 2011.

15. Khanal, N.R.; Mool, P.K.; Shrestha, A.B.; Rasul, G.; Ghimire, P.K.; Shrestha, R.B.; Joshi, S.P. A comprehensive approach and methods for glacial lake outburst flood risk assessment, with examples from Nepal and the transboundary area. Int. J. Water Resour. Dev. 2015, 31, 219-237. [CrossRef]

16. Cui, P.; Dang, C.; Cheng, Z.L.; Scott, K.M. Debris Flows Resulting From Glacial-Lake Outburst Floods in Tibet, China. Phys. Geogr. 2010, 31, 508-527. [CrossRef]

17. Komori, J.; Koike, T.; Yamanokuchi, T.; Tshering, P. Glacial Lake Outburst Events in the Bhutan Himalayas. Glob. Environ. Res. 2012, 16, 59-70. [CrossRef] 
18. Veh, G.; Korup, O.; Roessner, S.; Walz, A. Detecting Himalayan glacial lake outburst floods from Landsat time series. Remote Sens. Environ. 2018, 207, 84-97. [CrossRef]

19. Kershaw, J.A.; Clague, J.J.; Evans, S.G. Geomorphic and sedimentological signature of a two-phase outburst flood from moraine-dammed Queen Bess Lake, British Columbia, Canada. Earth Surf. Processes Landf. 2010, 30, 1-25. [CrossRef]

20. Worni, R. Challenges of modeling current very large lahars at Nevado del Huila Volcano, Colombia. Bull. Volcanol. 2012, 74, 309-324. [CrossRef]

21. Manville, V. Palaeohydraulic analysis of the 1953 Tangiwai lahar; New Zealand's worst volcanic disaster. Acta Vulcanol. 2004, 16, 1000-1015. [CrossRef]

22. Mergili, M.; Schneider, D.; Worni, R. Glacial Lake Outburst Floods (GLOFs): Challenges in prediction and modelling. In Proceedings of the 5th International Conference on Debris-Flow Hazards Mitigation: Mechanics, Prediction and Assessment, Rome, Italy, 14 June 2011; pp. 973-982.

23. Breien, H.; Blasio, F.V.D.; Elverhøi, A.; Høeg, K. Erosion and morphology of a debris flow caused by a glacial lake outburst flood, Western Norway. Landslides 2008, 5, 271-280. [CrossRef]

24. Iverson, R.M. Elementary theory of bed-sediment entrainment by debris flows and avalanches. J. Geophys. Res. Earth Surf. 2012, 117. [CrossRef]

25. Lugon, R.; Stoffel, M. Rock-glacier dynamics and magnitude-frequency relations of debris flows in a high-elevation watershed: Ritigraben, Swiss Alps. Glob. Planet. Chang. 2010, 73, 202-210. [CrossRef]

26. Pareek, N.; Sharma, M.L.; Arora, M.K. Impact of seismic factors on landslide susceptibility zonation: A case study in part of Indian Himalayas. Landslides 2010, 7, 191-201. [CrossRef]

27. Huang, R.; Li, W. Post-earthquake landsliding and long-term impacts in the Wenchuan earthquake area, China. Eng. Geol. 2014, 182, 111-120. [CrossRef]

28. Lin, C.W.; Shieh, C.L.; Yuan, B.D.; Shieh, Y.C.; Liu, S.H.; Lee, S.Y. Impact of Chi-Chi earthquake on the occurrence of landslides and debris flows: Example from the Chenyulan River watershed, Nantou, Taiwan. Eng. Geol. 2004, 71, 49-61. [CrossRef]

29. Osti, R.; Bhattarai, T.N.; Miyake, K. Causes of catastrophic failure of Tam Pokhari moraine dam in the Mt. Everest region. Nat. Hazards 2011, 58, 1209-1223. [CrossRef]

30. $\mathrm{Xu}, \mathrm{D}$. Characteristics of debris flow caused by outburst of glacial lake in Boqu river, Xizang, China, 1981 . GeoJournal 1988, 17, 569-580. [CrossRef]

31. Cook, K.L.; Andermann, C.; Gimbert, F.; Adhikari, B.R.; Hovius, N. Glacial lake outburst floods as drivers of fluvial erosion in the Himalaya. Science 2018. [CrossRef]

32. Guo, C.-w.; Huang, Y.-d.; Yao, L.-k.; Alradi, H. Size and spatial distribution of landslides induced by the 2015 Gorkha earthquake in the Bhote Koshi river watershed. J. Mt. Sci. 2017, 14, 1938-1950. [CrossRef]

33. Tanoli, J.I.; Ningsheng, C.; Regmi, A.D.; Jun, L. Spatial distribution analysis and susceptibility mapping of landslides triggered before and after Mw7. 8 Gorkha earthquake along Upper Bhote Koshi, Nepal. Arabian J. Geosci. 2017, 10, 277. [CrossRef]

34. Khanal, N.R.; Hu, J.M.; Mool, P. Glacial Lake Outburst Flood Risk in the Poiqu/Bhote Koshi/Sun Koshi River Basin in the Central Himalayas. Mt. Res. Dev. 2015, 35, 351-364. [CrossRef]

35. Petrov, M.A.; Sabitov, T.Y.; Tomashevskaya, I.G.; Glazirin, G.E.; Chernomorets, S.S.; Savernyuk, E.A.; Tutubalina, O.V.; Petrakov, D.A.; Sokolov, L.S.; Dokukin, M.D. Glacial lake inventory and lake outburst potential in Uzbekistan. Sci. Total Environ. 2017, 592, 228. [CrossRef] [PubMed]

36. Larsen, I.J.; Montgomery, D.R.; Korup, O. Landslide erosion controlled by hillslope material. Nat. Geosci. 2010, 3, 247. [CrossRef]

37. Lateltin, O.; Haemmig, C.; Raetzo, H.; Bonnard, C. Landslide risk management in Switzerland. Landslides 2005, 2, 313-320. [CrossRef]

38. Huggel, C.; Haeberli, W.; Kääb, A.; Bieri, D.; Richardson, S. An assessment procedure for glacial hazards in the Swiss Alps. CaGeJ 2004, 41, 1068-1083. [CrossRef]

39. Mckillop, R.J.; Clague, J.J. Statistical, remote sensing-based approach for estimating the probability of catastrophic drainage from moraine-dammed lakes in southwestern British Columbia. Glob. Planet. Chang. 2007, 56, 153-171. [CrossRef]

40. Wang, W.; Yao, T.; Gao, Y.; Yang, X.; Kattel, D.B. A first-order method to identify potentially dangerous glacial lakes in a region of the southeastern Tibetan Plateau. Mt. Res. Dev. 2011, 31, 122-130. [CrossRef] 
41. Cook, S.J.; Kougkoulos, I.; Edwards, L.A.; Dortch, J.; Hoffmann, D. Glacier change and glacial lake outburst flood risk in the Bolivian Andes. Cryosphere Discuss. 2016. [CrossRef]

42. Kougkoulos, I.; Cook, S.J.; Jomelli, V.; Clarke, L.; Symeonakis, E.; Dortch, J.M.; Edwards, L.A.; Merad, M. Use of multi-criteria decision analysis to identify potentially dangerous glacial lakes. Sci. Total Environ. 2018, 621, 1453-1466. [CrossRef]

43. Emmer, A.; Cochachin, A. The causes and mechanisms of moraine-dammed lake failures in the Cordillera Blanca, North Amerian Cordillera, and Himalayas. AUC Geogr. 2013, 48, 5-15. [CrossRef]

44. Westoby, M.J.; Glasser, N.F.; Hambrey, M.J.; Brasington, J.; Reynolds, J.M.; Hassan, M.A. Reconstructing historic Glacial Lake Outburst Floods through numerical modelling and geomorphological assessment: Extreme events in the Himalaya. Earth Surf. Processes Landf. 2014, 39, 1675-1692. [CrossRef]

45. Liu, J.J.; Cheng, Z.L.; Su, P.C. The relationship between air temperature fluctuation and Glacial Lake Outburst Floods in Tibet, China. Quat. Int. 2013, 321, 78-87. [CrossRef]

46. Rounce, D.R.; Mckinney, D.C.; Lala, J.M.; Byers, A.C.; Watson, C.S. A new remote hazard and risk assessment framework for glacial lakes in the Nepal Himalaya. Hydrol. Earth Syst. Sci. 2016, 20,1-48. [CrossRef]

47. Wang, X.; Liu, S.; Ding, Y.; Guo, W.; Jiang, Z.; Lin, J.; Han, Y. An approach for estimating the breach probabilities of moraine-dammed lakes in the Chinese Himalayas using remote-sensing data. Nat. Hazards Earth Syst. Sci. 2012, 12, 3109-3122. [CrossRef]

48. Fujita, K.; Suzuki, R.; Nuimura, T.; Sakai, A. Performance of ASTER and SRTM DEMs, and their potential for assessing glacial lakes in the Lunana region, Bhutan Himalaya. J. Glaciol. 2008, 54, 220-228. [CrossRef]

49. Clague, J.J.; Evans, S.G. A review of catastrophic drainage of moraine-dammed lakes in British Columbia. Quat. Sci. Rev. 2000, 19, 1763-1783. [CrossRef]

50. Haeberli, W.; Schaub, Y.; Huggel, C. Increasing risks related to landslides from degrading permafrost into new lakes in de-glaciating mountain ranges. Geomorphology 2016, 293. [CrossRef]

51. Das, S.; Kar, N.S.; Bandyopadhyay, S. Glacial lake outburst flood at Kedarnath, Indian Himalaya: A study using digital elevation models and satellite images. Nat. Hazards 2015, 77, 769-786. [CrossRef]

52. Lv, T.B.; Li, D. Introduction of Debris Flow Resulted from Glacial Lakes Failed; Sichuan University Publishing House: Chengdu, China, 1999.

53. O'Connor, J.E.; Baker, V.R. Magnitudes and implications of peak discharges from glacial Lake Missoula. GSAMB 1992, 104, 267-279. [CrossRef]

54. Huggel, C.; Kääb, A.; Haeberli, W.; Teysseire, P.; Paul, F. Remote sensing based assessment of hazards from glacier lake outbursts: A case study in the Swiss Alps. Can. Geotech. J. CaGeJ 2002, 39, 316-330. [CrossRef]

55. Stoffel, M.; Huggel, C. Effects of climate change on mass movements in mountain environments. Prog. Phys. Geogr. 2012, 36, 421-439. [CrossRef]

56. Cui, P.; Zhou, G.G.; Zhu, X.; Zhang, J. Scale amplification of natural debris flows caused by cascading landslide dam failures. Geomorphology 2013, 182, 173-189. [CrossRef]

57. Cui, P.; Zhuang, J.Q.; You, Y.; Chen, X.Q.; Scott, K.M. Landslide-dammed lake at Tangjiashan, Sichuan province, China (triggered by the Wenchuan Earthquake, May 12, 2008): Risk assessment, mitigation strategy, and lessons learned. Environ. Earth Sci. 2012, 65, 1055-1065. [CrossRef]

58. Fan, X.; Tang, C.X.; Westen, C.J.V.; Alkema, D. Simulating dam-breach flood scenarios of the Tangjiashan landslide dam induced by the Wenchuan Earthquake. Nat. Hazards Earth Syst. Sci. 2012, 12, 3031-3044. [CrossRef]

59. Li, W. Handbook of Hydraulic Calculations; Water Publication: Beijing, China, 1980. [CrossRef]

60. Liu, J.; You, Y.; Chen, X.; Liu, J.; Chen, X. Characteristics and hazard prediction of large-scale debris flow of Xiaojia Gully in Yingxiu Town, Sichuan Province, China. Eng. Geol. 2014, 180, 55-67. [CrossRef]

61. Wang, S.; Zhang, T. Spatial change detection of glacial lakes in the Koshi River Basin, the Central Himalayas. Environ. Earth Sci. 2014, 72, 4381-4391. [CrossRef]

62. Bajracharya, S.R. Glaciers, glacial lakes and glacial lake outburst floods in the Mount Everest region, Nepal. Ann. Glaciol. 2009, 50, 81-86. [CrossRef]

63. Jiang, S.; Nie, Y.; Liu, Q.; Wang, J.; Liu, L.; Hassan, J.; Liu, X.; Xu, X. Glacier Change, Supraglacial Debris Expansion and Glacial Lake Evolution in the Gyirong River Basin, Central Himalayas, between 1988 and 2015. Remote Sens. 2018, 10, 986. [CrossRef]

64. Gardelle, J.; Arnaud, Y.; Berthier, E. Contrasted evolution of glacial lakes along the Hindu Kush Himalaya mountain range between 1990 and 2009. Glob. Planet. Chang. 2011, 75, 47-55. [CrossRef] 
65. Bhambri, R.; Bolch, T. Glacier mapping: A review with special reference to the Indian Himalayas. Prog. Phys. Geogr. 2009, 33, 672-704. [CrossRef]

66. Wang, W.; Xiang, Y.; Gao, Y.; Lu, A.; Yao, T. Rapid expansion of glacial lakes caused by climate and glacier retreat in the Central Himalayas. Hydrol. Process. 2015, 29, 859-874. [CrossRef]

67. Emmer, A. Geomorphologically effective floods from moraine-dammed lakes in the Cordillera Blanca, Peru. Quat. Sci. Rev. 2017, 177, 220-234. [CrossRef]

68. Wilson, R.; Glasser, N.F.; Reynolds, J.M.; Harrison, S.; Anacona, P.I.; Schaefer, M.; Shannon, S. Glacial lakes of the Central and Patagonian Andes. Glob. Planet. Chang. 2018, 162. [CrossRef]

69. Emmer, A.; Vilímek, V.; Huggel, C.; Klimeš, J.; Schaub, Y. Limits and challenges to compiling and developing a database of glacial lake outburst floods. Landslides 2016, 13, 1579-1584. [CrossRef]

70. Clarke, G.K.C.; Mathews, W.H.; Pack, R.T. Outburst floods from glacial Lake Missoula. Quat. Res. 1984, 22, 289-299. [CrossRef]

71. Martha, T.R.; Roy, P.; Mazumdar, R.; Govindharaj, K.B.; Kumar, K.V. Spatial characteristics of landslides triggered by the $2015 \mathrm{M}$ w 7.8 (Gorkha) and M w 7.3 (Dolakha) earthquakes in Nepal. Landslides 2016, 1-8. [CrossRef]

72. Kargel, J.; Leonard, G.; Shugar, D.H.; Haritashya, U.; Bevington, A.; Fielding, E.; Fujita, K.; Geertsema, M.; Miles, E.; Steiner, J. Geomorphic and geologic controls of geohazards induced by Nepal's 2015 Gorkha earthquake. Science 2016, 351, aac8353. [CrossRef]

(C) 2020 by the authors. Licensee MDPI, Basel, Switzerland. This article is an open access article distributed under the terms and conditions of the Creative Commons Attribution (CC BY) license (http://creativecommons.org/licenses/by/4.0/). 